\title{
"Benchmarking study on the venture capital market in the Czech Republic, Hungary and the Netherlands"
}

$\begin{array}{ll}\text { AUTHORS } & \text { Ing. Jaroslava Rajchlová } \\ \text { Ing. Veronika Svatoaová }\end{array}$

Ing. Jaroslava Rajchlová and Ing. Veronika Svatoaová (2016). Benchmarking

ARTICLE INFO study on the venture capital market in the Czech Republic, Hungary and the Netherlands. Investment Management and Financial Innovations, 13(3-1), 191202. doi:10.21511/imfi.13(3-1).2016.05

DOI http://dx.doi.org/10.21511/imfi.13(3-1).2016.05

RELEASED ON Friday, 23 September 2016

JOURNAL "Investment Management and Financial Innovations"

FOUNDER LLC "Consulting Publishing Company "Business Perspectives"

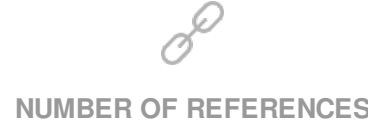

0

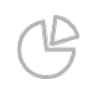

NUMBER OF FIGURES

0

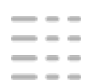

NUMBER OF TABLES

0

(C) The author(s) 2022. This publication is an open access article. 
Ing. Jaroslava Rajchlová (Czech Republic), Ing. Veronika Svatošová (Czech Republic)

\title{
Benchmarking study on the venture capital market in the Czech Republic, Hungary and the Netherlands
}

\begin{abstract}
The main aim of paper is seen at two levels: the first level to assess the situation on the venture capital market in the Czech Republic based on the results of a comparative study of selected countries of European Union is the area of venture capital financing. The second level is, then, to propose measures, whose implications could increase the effectiveness of venture capital to the business sector in the Czech Republic. The main purpose of the paper is to identify internally homogeneous groups of the EU states regarding the situation on the venture capital market in the European Union Member States. The aim of this article is supported by relevant statistical data for the period 20082013 to assess the legislative framework of venture capital market in the Czech Republic and other selected European countries. Based on the results of cluster analysis, EU countries were identified, Hungary and the Netherlands, in which legislative conditions with venture capital market were subsequently analyzed and the results were compared with the situation in the Czech Republic. The Netherlands as a representative of the countries with developed market risk capital, Hungary as a representative of CEE countries. The problem of undeveloped VC market in the Czech Republic is not in demand for venture capital, but in its supply. Pension funds and insurance companies cannot invest more than $5 \%$ in risky assets. In the Czech Republic, there are no tax incentives to attract investors and even government programs that could complement the missing investors and support the creation of venture capital funds. This low level of venture capital usage for the development of enterprises could also be seen in misunderstanding and ignorance of this form of financing, the inability of management to prepare a business plan and to attract a potential investor, fears of administrative burdens arising from an investor and finally questionable return on investment when, for example, public offering of shares, which achieves a high appreciation, is in the Czech Republic underused.
\end{abstract}

Keywords: venture capital, benchmarking, cluster analysis, Ward's method, CEE countries, EU countries, Czech Republic, Hungary, Netherlands.

JEL Classification: G32, M21.

\section{Introduction}

According to the definition of the European Association for Private Equity Venture Capital (hereinafter EVCA) with financing through venture capital refers to providing the equity capital to companies emitting no shares. Depending on the life stage-funded enterprise, we can distinguish the following forms of Private Equity: Venture Capital, Growth Capital, Replacement Capital, Rescue / Turnaround Capital and Buyouts.

Venture capital providers are either private investors (Business Angels) or institutional investors (Venture Capital Funds). Their aim is an adequate return on capital invested by reference to the risk undertaken. The aim of the using the private equity on the part of enterprises is, for example, the development of new products and technologies, expansion of business activities (implementation of an expansion strategy), or strengthening its capital structure (e.g., Busse, 2003; Geyer, Hanke, Litt, 2006; Valach, 2006).

(C) Ing. Jaroslava Rajchlová, Ing. Veronika Svatošová, 2016.

Ing. Jaroslava Rajchlová, Ph.D., Assistant Professor at Mendel University in Brno, Faculty of Regional Development and International Studies, Department of Regional and Business Economics, Czech Republic.

Ing. Veronika Svatošová, Ph.D., Assistant Professor at Mendel University in Brno, Faculty of Regional Development and International Studies, Department of Regional and Business Economics, Czech Republic.
Functioning market with venture capital positively stimulates the business environment, i.e., it supports the creation of new businesses and their increased competitiveness, contributing to the creation of new jobs and ultimately has a positive effect on economic growth of national economies (Engel, 2001; Nývltová, Režňáková, 2007; Roling, 2001).

The venture capital market as an alternative form of corporate financing in North America and Western Europe and in the modern concept is continuously developing since the late $19^{\text {th }}$ century. The Czech Republic is drawn into the events of the 90s of the twentieth century. Investors (Limited Partners), an investment company (General Partners) and funded enterprises (Investee Companies) have become an integral part of the financial market. According to figures from EVCA only between 2000 and 2004, European enterprises financed through Private Equity have created more than 1 million jobs and recorded employment growth on averaged at 5.4\%, while in the same period, the growth rate of total employment in the EU25 was $0.7 \%$.

Financing of the development of private enterprises in the form of venture capital is an alternative way to a wide range of other forms of business financing. Properties of business development financing in the form of venture capital can be based on a review of selected approaches and the conclusions drawn from the findings (Rajchlová et al., 2012). The use of venture capital in developed economies is an 
obvious part of corporate financing through the capital market (Rajchlová et al., 2012). For example, the success of Silicon Valley in the USA is currently tied with venture capital financing. The economic upswing in Germany in the 80's of the last century was essentially financed by this type of capital (Schefcyk, 2006). Legislative conditions are an important consideration when mapping the situation on the venture capital market in the Czech Republic. An important impetus for the current situation is a comparison of legislative conditions with other countries of the European Union.

Studies evaluating the activities of the countries in the area of venture capital are the basis of the present research project. This is especially the annually published study EVCA. However, the purpose of the paper is to choose states based on the use of statistical methods, which are identified as internally homogeneous groups of states of the European Union regarding the situation on the venture capital market in the Member States of the European Union and, then, to select those states that have higher levels of using the venture capital. The paper will analyze and, then, compare the legislative environment of individual states.

The main aim of paper is seen at two levels: the first level to assess the situation on the venture capital market in the Czech Republic based on the results of a comparative study of selected countries of European Union is the area of venture capital financing. The second level is, then, to propose measures, whose implications could increase the effectiveness of venture capital to the business sector in the Czech Republic. Comparative study is based on Cluster analysis method. As results of Cluster analysis, the Czech Republic, the Netherlands and Hungary were selected (reasoning in methodology and results).

Due to the high specification of this paper, with emphasis on the comparison of the legislative environment in the Czech Republic and selected states, there is no relevant literature or scientific papers dealing with the specific topic. Therefore, the theoretical framework is focused on the previous studies and researches dealing with the issue of venture capital financing in general.

\section{Theoretical framework}

According to the definition of the European Association for Private Equity Venture Capital (hereinafter EVCA), financing through Private Equity means to provide equity capital to companies emitting no shares. Depending on the life stage of funded enterprise, we can distinguish the following forms of Private Equity: Venture Capital, Growth
Capital, Replacement Capital, Rescue / Turnaround Capital and Buyouts.

Venture capital providers are either private investors (i.e., Business Angels) or institutional investors (i.e., Venture Capital Funds). Their goal is an adequate return on capital invested by reference to the risk undertaken. The aim is the use of risk capital on the part of enterprises, e.g., development of new products and technologies, expansion of business activities (implementation strategy of expansion), or strengthening its capital structure (e.g., Busse, 2003; Geyer, Hanke, Litt, Nettekoven, 2006; Valach, 2001).

Functioning venture capital market positively stimulate business environment, i.e., supports the creation of new businesses and increases the competitiveness, contributes to the creation of new jobs and ultimately has a positive effect on economic growth of national economies (Engel, 2001; Nývltová, Režňáková, 2007; Roling, 2001).

Venture capital market as an alternative form of corporate finance in North America and Western Europe in the modern concept is developed continuously since the late $19^{\text {th }}$ century. The Czech Republic is drawn into the events since the 90s of the twentieth century. Investors (i.e., Limited Partners), an investment company (i.e., General Partners) and funded enterprises (i.e., Investee Companies) have become an integral part of the financial market. According to data from EVCA, only between 2000 and 2004 European companies financed by venture capital werecreated more than 1 million jobs and recorded an employment growth on average at $5.4 \%$, while in the same period, the growth rate of total employment in the EU25 was $0.7 \%$. After an extremely successful period $2005-$ 2007, the European market for Private Equity was affected by the financial and economic crisis.

The actual issue of venture capital is based on demonstrably positive impact on the development of enterprises and the development of the national economy. Based on the analysis of the results of numerous foreign studies, the positive effect of venture capital financing for the development of enterprises and the development of national economies can be confirmed. These include the study of EVCA (2001), NVCA (2002), BVCA (2002), AVCO (2006), or the studies by the authors Engel (2001), Roling (2001) and Penedel, Jud (2004). These confirm the positive effect of venture capital financing for the development of enterprises in the areas of employment, innovative capacity of the company, reporting rate of patents and development financing of PE/VC. 
Many studies are exploring the issue of venture capital that have been already published (Rajchlová, Fedorová, Svatošová, 2014). E.g., Jain and Kini (1995) conducted the research of 136 companies that were financed by venture capital; the results showed that the support of venture capital has a positive impact on higher employment and revenue growth in comparison with companies that are funded by other forms of financing (control group). The similar research was made by Lerner (1999), which aimed to compare companies funded by venture capital with control group. The research presented the companies financed by venture capital showed three to four times higher rate of growth in selected indicators - employment and sales than the control group. Based on internal data of surveyed companies, Engel and Keilbach (2002) studied the impact of venture capital on the number of patent announcement. The authors assume that venture capital investors finance more innovative companies, but afterward strengthen its activities in the form of product placing on the market and, thus, increase the speed of the business development. Manigart, Hyfte (1999) were focused on the survey that showed the companies financed by venture capital and do not have expressively higher employment growth, but have a higher rate of growth in assets and cash flow. In the research, 187 Belgian companies financed by venture capital were compared with the control group of companies.

\section{Materials and methods}

The basis for drafting the comparative study was to use statistical methods of cluster analysis. The purpose was to identify internally homogeneous groups of the EU states regarding the situation on the venture capital market in the European Union Member States. The main aim of paper is seen at two levels: the first level to assess the situation on the venture capital market in the Czech Republic based on the results of a comparative study of selected countries of European Union is the area of venture capital financing. The second level is, then, to propose measures, whose implications could increase the effectiveness of venture capital to the business sector in the Czech Republic.

Its results will be used to define the group of countries with a similar level of venture capital investment. The aim of this article is supported by relevant statistical data for the period 2008-2013 to assess the legislative framework of venture capital market in the Czech Republic and other selected European countries. The criteria for determining appropriate levels of data were used, i.e., the characteristics of supply and demand for venture capital.

The supply is characterized by:
- The share of financial deposit, which have venture capital funds to GDP (fundraising/GDP).

- Total size of the investment, expressed as a percentage of GDP in the national territory (investment/GDP).

- The share of VC investments to PE (VC/PE).

The demand for venture capital is, then, characterized by the following features:

- The share of expenditure on R\&D to GDP (R\&D/GDP).

- Sequence in the evaluation of difficulty with starting up a business by Doing Business.

The main materials were based on data of $22 \mathrm{EU}$ countries force on 31/12/2014, taken from a database of EVCA, Eurostat and Doing Business. Data for some countries (Malta and Cyprus) are not tracked because of their activity in the market with venture capital is very low or zero (Malta and Cyprus). Some countries in the database EVCA are monitored in groups because of their geographical proximity, interconnectivity and the difficulty of obtaining the necessary data for individual countries. These are the Baltic States (Lithuania, Latvia, Estonia), and a group consisting of Slovenia, Slovakia and Croatia. Values of some characters for these groups were calculated as the sum of the characteristics of individual states (GDP, R\&D) or as an average value of national symbols (business environment). Subsequently, the data were standardized.

To fulfil this aim, it was necessary to identify the correct method of data processing. Given the need to assemble a group of states that exhibit similarities in the legislative framework for venture capital, the cluster analysis was used. Clustering process was conducted in STATISTICA 12. Cluster analysis is formulated as a procedure, by which we group together individuals or units into groups based on their similarities and differences. (Hebák, 2007). There are different approaches to clustering, i.e., nearest neighbor method, furthest neighbor method, centring method, pairwise distance method and Ward's method. For study evaluation, the Ward's method was selected as the most effective method that is based on analysis of variance. Ward's method combines those clusters, where the minimum sum of squares is used. It tends to form relatively small clusters. As a metric distance, the Euclidean distance was used.

The source of the data contained in these documents is a statistical platform PEREP Analytics tracking a development of Private Equity and Venture Capital in 25 European countries. Statistical PEREP Analytics platform is a joint activity EVCA and 18 
national associations of companies investing Private Equity and Venture Capital. Statistical data are basically evaluated from two perspectives: the first one is the headquarters of company investing Private Equity and Venture Capital (i.e., investments by country of management - industry statistics), the other one is the headquarter of funded business entity (i.e., investments by country of portfolio management - market statistics). As a results of cluster analysis, the Czech Republic, Hungary and the Netherlands for comparative study was selected (see details in results).

Limitations of this comparative study are seen in the selection of that year, i.e., 2014. Nevertheless, this limitation is not considered by authors as significant, since it cannot be assumed the changes in legislation the Netherlands and since the venture capital in Netherlands has been greatly entrenched.

\section{Results}

The Figure 1 shows the process of linking the various objects, i.e., countries into groups. The clustering process will be terminated at the best moment to join a cluster of Bulgaria, Slovakia \& Slovenia \& Croatia, Hungary and Luxembourg to a cluster of Czech Republic, Poland and Spain. This moment is shown in Figure 1 by a red vertical. Based on the results of cluster analysis, we can identify eight clusters.

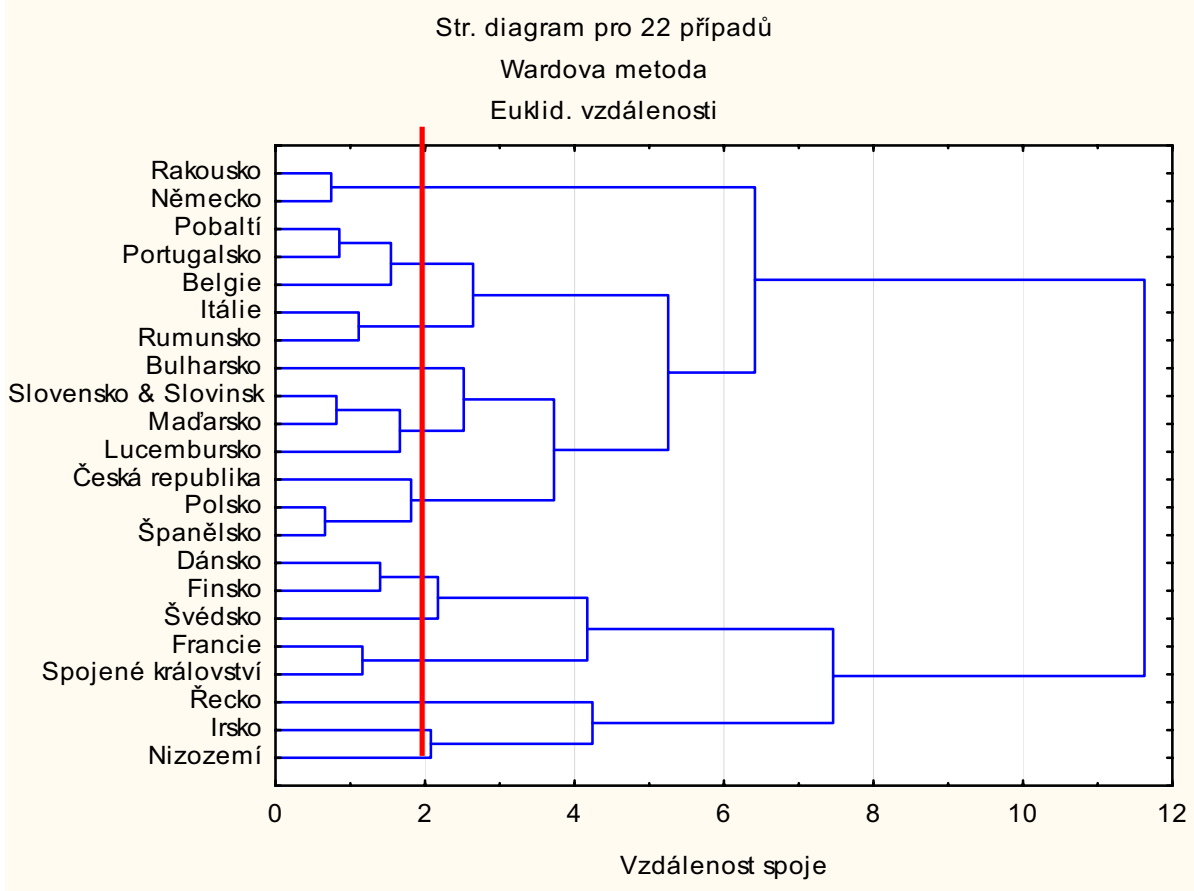

Source: own in program STATISTICA 12.

Note: Diagram for 22 countries based on Ward's method and Euclidean distance with distance connections (in the picture as Vzdálenost spoje).

Legend: Rakousko - Austria, Německo - Germany, Pobaltí - Baltic countries, Portugalsko - Portuguese, Belgie - Belgium, Itálie - Italy, Rumunsko - Romania, Bulharsko - Bulgaria, Slovensko \& Slovinsko - Slovakia \& Slovenia, Mad'arsko - Hungary, Lucembursko Luxemburg, Česká republika - Czech Republic, Polsko - Poland, Španělsko - Spain, Dánsko - Denmark, Finsko - Finland, Švédsko Sweden, Francie - France, Spojené království - United Kingdom, Recko - Greece, Irsko - Ireland, Nizozemí - Netherlands.

\section{Fig. 1. Dendrogram of cluster analysis}

Table 1 clearly describes the distribution of individual EU countries into groups as a result of cluster analysis. Sorting of cluster is designed hierarchically from clusters containing states, which are assessed as favorable for venture capital investments, to clusters, including those states where the market situation with venture capital is not good. Clusters No. 8,5,6,1 indicated the group of states that perform good results on the venture capital market, Clusters No. 2,3,4,7 indicated the group of states, whose venture capital market is problematic. Building the cluster sis determined from the best to worst overall results (for detailed description, see Table 1).

Table 1. Typology of EU countries according to the situation on the venture capital market

\begin{tabular}{|c|l|l|l|}
\hline & \multicolumn{1}{|c|}{ Signification } & \multicolumn{1}{c|}{ Country } & \multicolumn{1}{c|}{ Cluster } \\
\hline $\begin{array}{c}\text { Countries with } \\
\text { good results on } \\
\text { the venture } \\
\text { capital market }\end{array}$ & Cluster 8 & Netherlands, Ireland & $\begin{array}{l}\text { High activity on the venture capital market, easy setting up companies, VC } \\
\text { creates most PE. }\end{array}$ \\
\cline { 2 - 4 } & Cluster 5 & Denmark, Finland, Sweden & High activity on the venture capital market, easy setting up companies. \\
\hline
\end{tabular}


Table 1 (cont.). Typology of EU countries according to the situation on the venture capital market

\begin{tabular}{|c|c|c|c|}
\hline & Signification & Country & Cluster \\
\hline & Cluster 6 & United Kingdom, France & $\begin{array}{l}\text { Higher activity on the venture capital market, investments do not reach } \\
\text { the amount of monetary funds that are in the venture capital funds. }\end{array}$ \\
\hline & Cluster 1 & Germany, Austria & $\begin{array}{l}\text { Despite the high expenditure on research and development, countries do } \\
\text { not reach the level of venture capital activity as clusters above. }\end{array}$ \\
\hline \multirow{4}{*}{$\begin{array}{l}\text { Counties with } \\
\text { problematic } \\
\text { results on the } \\
\text { venture capital } \\
\text { market }\end{array}$} & Cluster 2 & $\begin{array}{l}\text { Baltics countries, Portugal, Belgium, } \\
\text { Italy, Romania }\end{array}$ & $\begin{array}{l}\text { Local venture capital funds do not have sufficient financial resources, } \\
\text { innovative enterprises, thus, are financed from abroad. }\end{array}$ \\
\hline & Cluster 3 & $\begin{array}{l}\text { Bulgaria, Slovakia, Slovenia, Croatia, } \\
\text { Hungary, Luxemburg }\end{array}$ & $\begin{array}{l}\text { Local venture capital funds do not have sufficient financial resources, } \\
\text { innovative enterprises, thus, are financed from abroad }\end{array}$ \\
\hline & Cluster 4 & Czech Republic, Poland, Spain & $\begin{array}{l}\text { Underdeveloped venture capital markets, both in terms of demand and in } \\
\text { terms of supply. }\end{array}$ \\
\hline & Cluster 7 & Greece & $\begin{array}{l}\text { The least developed venture capital markets, very low expenditure } \\
\text { on R\&D. }\end{array}$ \\
\hline
\end{tabular}

Source: own.

\section{Comparative study of the Czech Republic, the Netherlands and Hungary}

Processing the benchmarking study on venture capital market and the subsequent identification of possible barriers and opportunities, an assessment were required to be determined. Based on the analysis of documentary sources from the OECD (2004, 2014) and European Commission (2012, 2015a), the definition of these determinants was preceded:

1. Investment environment - particularly the involvement of institutional investors, i.e. pension funds, and barriers to foreign investment in venture capital, support for expenditure on research and development, cooperation between clusters of enterprises, universities and other stakeholders.

2. Legislation/tax system - the legal form of funds, tax relief for investors, the risk of double taxation, terms of patents, the difficulty of starting up a business, dealing the insolvency.

3. Supporting programs at national and EU level the use of EU supporting programs, supporting programs at the state level.

Based on the results of cluster analysis, three countries were chosen: the Netherlands, Czech Republic and Hungary, their level of venture capital market is sufficiently different, and barriers for the development of venture capital markets can be expected to be founded. Table 2 shows the values that entered into a cluster analysis.

Table 2. Values, activities with venture capital in selected countries

\begin{tabular}{|l|c|c|c|c|c|}
\hline \multicolumn{1}{|c|}{ Country } & Fundraising/HDP & Investment/GDP & VC/PE & R\&D/GDP & $\begin{array}{c}\text { Difficulty with starting up a } \\
\text { business }\end{array}$ \\
\hline Netherlands & $0.0124 \%$ & $0.0321 \%$ & $55.70 \%$ & $2.1144 \%$ & 21 \\
\hline Hungary & $0.0150 \%$ & $0.0176 \%$ & $30.40 \%$ & $1.4447 \%$ & 57 \\
\hline Czech Republic & $0.0000 \%$ & $0.0019 \%$ & $2.10 \%$ & $2.0046 \%$ & 110 \\
\hline
\end{tabular}

Source: own based on EVCA, Eurostat, Doing Business.

\section{The Czech Republic}

\section{Investment environment}

The issue of pension funds in the Czech Republic differs from functioning in other European countries. In the Czech Republic on 1 January 2016, the second pension pillar is cancelled and only the first pillar exists, controlled by the state, and the third pillar, which represents the supplementary pension insurance. Designated use of funds by private pension funds is, thus, limited. Pension funds of the third pillar are highly restricted both quantitatively and qualitatively in relation to their investment portfolio. Funds of the third pillar, incurred before the pension reform in 2012, are known as transformed pension funds. They may 5\% of its assets allocate to alternative assets, including venture capital. The problem is that the current guaranteed return of pension funds leads to a conservative investment strategy, with the exclusion of venture capital. Other funds of the third pillar arising after the pension reform, the so-called participating funds allow to clients to choose the investment strategy, but these funds cannot invest in venture capital funds. Insurance companies have a similar problem, such as pension funds. The law has determined, in what assets they can invest, where VC is not listed.

The Czech Republic has implemented into its legislation AIFMD with effect from 19/8/2013, in the form of Act 240/2013 Coll., On Investment Companies and Investment Funds (hereinafter AICIF). Problematic interpretation of Czech law lies primarily in a marketing of management companies with headquarters outside the EU. In this respect, the amendment of AISIF can be expected. To a lighter regime EuVECA, no management company in the CR is registered. Like the Netherlands, the Czech Republic 
has not ratified the agreement on the Unitary Patent Court yet. The cost on registering a patent is based on approximately 6,000 CZK, with the European Patent CZK 9,000. Renewal fees are paid from the first year and start at the amount of CZK 1,000 per year and increase to the amount of CZK 24,000 in the $20^{\text {th }}$ year (Úřad průmyslového vlastnictví, 2011).

The research and development is supported by the following programs: POTENTIAL, GESHER/ MOST, GAMA, DELTA, EPSILON, EUROSTARS. Furthermore, in the Czech Republic, the Competence Centres are allocated, furthermore the operational programs designed to promote research, development and innovation for the period 20142020. This is the OP Enterprise and Innovation for Competitiveness and OP Research, Development and Education.

The Czech Republic also provides significant tax incentives. This is a deduction of up to $200 \%$ of the costs associated with the implementation of research and development projects (including wages), 10-year exemption from income tax and technology transfer centres (Act no. 586/1992 Coll., On Income Tax). This review confirms that the Czech Republic is relatively strong culture of investment in research and development, representing over $2 \%$ of GDP. Problem of venture capital activities can be, thus, founded on the demand side of investment environment.

\section{Legislative and tax environment}

According to Doing Business (World Bank, 2015c), the Czech Republic is generally assessed in the ease of doing business at $44^{\text {th }}$ position. Ranking in the ease of starting up a business $-110^{\text {th }}$ place, the tax burden $119^{\text {th }}$ place, dealing insolvency $-20^{\text {th }}$ place.

In the Czech Republic, collective investment funds may have a structure of mutual fund or investment fund as a Joint Stock Company. With a validity of AISIF in August 2013, new legal forms of collective investment funds and VC funds have been created we may have an investment fund as a joint stock company with variable capital (hereinafter SICAV). The advantage of SICAV is that issues two classes of shares, founding and investment shares that allow the exit in the form of redemption, and so it will be easier to collect funds from a wide range of investors. Investment funds of qualified investors will be able to work well under the legal form as a Limited Partnership on Investment Sheets (hereinafter SICAR). This form corresponds to the foreign Limited Liability Partnership, which is dominating by $\mathrm{PE} / \mathrm{VC}$ funds in the world. The main advantage is seen primarily in fiscal transparency, flexible capital structure and a low level of regulation. In the Czech Republic, however, this legal form is handicapped compared to other legal forms; the fund in this form are subject to the tax on dividends and capital gains and also capital losses on venture capital investments are not tax deductible items.

Investment funds are subject to $5 \%$ of income tax by 2015 , even though it was a fiscally transparent legal form. Since 2015, the tax rate for investment funds is $0 \%$, and, therefore, the first double taxation is eliminated. Capital gains tax is $15 \%$ and for nonresidents, it only applies if the Czech Republic does not sign the contract with other countries. Fund management is not subject to VAT.

In connection with the ease of starting up a business, the Czech Republic is ranked at $110^{\text {th }}$ place in the world. The entire process of business registration takes on average of 19 days and consists of 9 treatments - registration of trademarks, criminal records and land registry, notarization, obtaining confirmation of administrator of capital, registration in the Trade and Companies Register, tax registration, registration of a payer of social and health insurance. The entire process is based on approximately 27000 CZK (World Bank, 2015a).

In case of dealing insolvency, the Czech Republic has placed among the top places. This dealing takes on average of 2.1 years and costs constitute $17 \%$ of the assets of the company. An enterprise may go through liquidation or reorganization and the rate of recovery of the company is $65.6 \%$.

\section{Supporting programs at the state level}

No program is still occurred in CR that would directly support venture capital investments. During the existence of the independent Czech Republic, there were two attempts at the formation of a venture capital fund with the participation of public monetary funds. The first Czech fund, venture capital fund (hereafter VCF), was established in 1995 and until 2000 nine companies have entered into the und. However, in 2000, it required for liquidation and its portfolio were sold under disadvantageous conditions. The reason for the liquidation of the fund was particularly the law and subsequent illegal status of fund (Pazour, Marek, 2011).

In 2005, in cooperation with CzechInvest and the Ministry of Industry and Trade (MIT), a draft supporting SMEs through venture capital fund has been prepared, where less than half of the monetary funds consisted of public resources, the rest would be from private investors. However, this proposal was not approved.

The latest initiative of MIT is the concept: seed Fund. Seed Fund was designed as part of OP Enterprise and Innovation for the programming 
period 2007 - 2013. Funds in Seed Fund should provide the European Regional Development Fund and the state budget of the CR. However, in April 2014, MIT issued a decision to cancel the tender for providing the services of management companies. The main reason was the lack of time to implement the OP, which is open until the end of 2015, legislative changes in relation to AISIF. MIT plans to return to the project in terms of the OP Enterprise and Innovation for Competitiveness. However, this proposal was not submitted.

In the Czech Republic, there are several management companies that manage funds, in which the EIF invests. They are: Mid Europa Partners, Syntaxis Capital, Enterprise Investors, East Accession BV, Darby Private Equity, 3TS Capital Partners. Only Pontis Venture Partners and Early Bird focus on investments in companies in their early stages (European Commission, 2015b).

\section{The Netherlands}

\section{Investment climate}

During the economic crisis in the Netherlands, the institutional investors in the structure of investors have completely disappeared. Dutch bank and insurance company DSB ceased its activities in 2009 and the banking group ABN-AMRO Group NV was nationalized in 2009 after serious problems with liquidity. As a result, a lot of banks, insurance companies and pension funds have been compelled to restrict their participation in risky assets (Koëter, 2012).

Currently, in the Netherlands, the pension fund must have a sufficient liquidity to be able to pay pensions, but no limits on pension fund investments by type of asset were imposed, it is only a requirement of diversification (OECD, 2014). The question is how the requirements will change with the newly planned IORP II Directive.

The same regime as for pension funds also applies to insurance companies. There are demands on their liquidity, which are based on the potential loss on the income statement. In January 2016, Solvency II Directive should be in validity. Dutch insurance companies are very well prepared for the requirements of Solvency II (De Nederlandsche Bank, 2011). It can be, therefore, assumed that the structure of the investors in the Netherlands does significantly affect this Directive.

Regarding the implementation of AIFMD (2014), the Netherlands incorporated the necessary laws into its legislation within the FSA, the Financial Supervision Act (Wet op het financieel toezichit), 22/7/2013. In the Netherlands, the license AIFM provides the Dutch central bank. Into the milder and voluntary regime EuVECA in the Netherlands, two management companies LSP Management Group BV and The Thuja Capital Management BV were included.

From the perspective of supply of investment environment in the Netherlands, many programs supporting the research and development have been introduced. The Netherlands belong among the countries that have not ratified the agreement on the Unitary Patent Court yet and, therefore, for the country, it is possible to apply for registration of a national or European patent. Cost of patent registration is 220 Euros for national registration and 914 Euros for a European patent. Renewal fees for a patent are valid from the $4^{\text {th }}$ year of registration and starts at amount of 40 Euros, it annually increased and ends at the amount of 2,400 euros. If you are applying for a European patent registered in the Netherlands, it is necessary to consider the additional fees such as transaction fee for international application 50 euros or fee for the application translated into Dutch of 25 euros (Netherlands Enterprise Agency, 2015).

Research and development in the Netherlands is supported by these programs: MIT-IPC (Innovatieprestatiecontracten), TKI (Topconsortia voor Kennis en Innovatie), RDA (Research and Development Aftrek), Innovatiebox, Programma Groeiversneller, Small Business Innovation Research (SBIR) programma, Wet Bevordering Speur en Ontwikkelingswerk (WBSO), Eurostars.

\section{Legislative and tax environment}

According to Doing Business (World Bank, 2015c), the Netherlands is placed on $27^{\text {th }}$ place in the world in evaluating the simplicity of business. In the ease of starting up a business, the country is on the $21^{\text {st }}$ position, in tax burden it is on 23th place and in the field of dealing insolvency it is on $12^{\text {th }}$ place.

According to these three parameters, it can be argued that the Netherlands is a country friendly to entrepreneurs. In the Netherlands, VC funds may have different structures. The most common is a Limited Partnership, Commanditaire Vennootschap (hereinafter $\mathrm{CV}$ ). Additionally, there may be a Limited Liability Company, Bestolen Vennootschap (hereafter BV) or cooperative Co-op.

VC funds can always find a suitable form of structure depending on what investors they want to focus on and whether they want to avoid the risk of double taxation. It is also preferred that the activity of management companies of $\mathrm{VC}$ fund is not subject to VAT. Capital gains of funds are exempt from the corporate income tax, if the shareholders do not own $5 \%$ or more of the capital. Capital gains of individuals are exempt if these people do not have a 
$5 \%$ or more share in the company. In this case, it is a $25 \%$ tax rate. The shortcoming can be considered a high corporate income tax, which is above the EU average and amounts to 20-25\% (EVCA, 2013).

In terms of insolvency, the Netherlands are assessed positively. On average, it takes 1.1 years and costs are around $3.5 \%$ of the company. During the insolvency, the company can pass both reorganization and liquidation. The rate of recovery is $88.9 \%$.

Even the establishment of enterprises in the Netherlands is positively evaluated compared to other European countries. The whole process takes 4 days and consists of 4 treatments, registration of business names, signing the memorandum, company registration, tax registration. Fees for the entire process are around 1800 Euros.

\section{Support programs at national level}

Programs organized by the Dutch government to support the activities of venture capital in the country are following: Seed Capital-Regeling, Groeifaciliteit, PPM Oost.

In the Netherlands, there are several VC management companies that generate funds, in which EIF invests. It is: Partech International, Vendis Capital, Metric Capital Partners, Metha Capital, Gilde Equity Management Benelux Partners, Capital Partners Holding B.V. In terms of CIP program (predecessor of COSME), the management company Karmijn Kapitaal Management is operating, whose VC funds focus on businesses in the stages of development (EVCA, 2013).

\section{Hungary}

\section{Investment climate}

In Hungary, the pension funds can invest only $5 \%$ of its assets in venture capital, including VC fund. The same conditions apply to insurance companies. They can invest 5\% of its assets in $\mathrm{PE} / \mathrm{VC}$ funds, geographical restrictions do not apply here.

Hungary transposed the directive AIFMD into its legislation in the form of XCI Act, 2014 March 16, 2014, about nine months after the deadline. No management company based in Hungary was registered to a lighter regime EuVECA (EVCA, 2014).

Hungary has the lowest spending on research and development of the three countries being compared, expressed as a share of GDP to research and development that represents about $1.4 \%$. Programs supporting the research and development are the following: Hungarian Scientific Research Fund (Otka), National Research, Development and Innovation Fund (NKFIA) Bilateral S\&T International Cooperation, Eurostars.

Hungary also strongly supports the research and development through EU programs. For the period
2007-2013 in the country, there was a program EDOP, Economic Development Operational Programme, for which a total of over 3 billion Euros has been allocated, for the research and development 990 mil. euros. Outside these supporting programs, the Hungarian government also provides tax incentives. This is a $200 \%$ reduction in costs associated with research and development, including wages, up to $50 \%$ deduction of royalties from income tax, exemption from capital gains associated with the patent exemption from social security of employees in research and development with academic titles.

Hungary belongs to the countries that have not signed an agreement on the Unitary Patent Court yet. The country has two modes, a national patent and European patent. Registration fees in the national system is approximately 460 euros, renewal fees start at 60 euros in the first year and up to 550 euro in the $20^{\text {th }}$ year. The European regime is necessary to count on 80 euros for each translation. Renewal fees start at 60 euros and up to 550 euros. (Hungarian Intellectual Property Office, 1996-2014).

\section{Legislative and tax environment}

Hungary is at $54^{\text {th }}$ place, according to the World Bank's evaluation of the difficulty with business. Ranking of Hungary in the evaluation of selected parameters is following: ease of starting up a business $-57^{\text {th }}$ place, the tax burden $-88^{\text {th }}$ place, dealing insolvency $-64^{\text {th }}$ place.

Excluding solutions insolvency Hungary achieves better results than the Czech Republic, although the overall assessment is placed behind the Czech Republic.

Hungary in terms of legislation and tax conditions for $\mathrm{VC}$ funds provides a good environment in Europe. In the country, there are two forms of structure funds, PE funds or investment funds. Foreign funds may also take the form of Limited Liability Company (Kft.) or Joint Stock Company (Zrt.), which is more often used.

Tax transparency of VC funds is ensured by the fact that the two structures of the funds are exempt from income tax. Fund management fees are exempt from VAT. Residents' capital gains are taxed at $16 \%$; by non-residents, it is important if an agreement on avoidance of double taxation exists between Hungary and other countries. The corporate income taxis also favorable, in case of the companies whose tax base is less than 500 mil. HUF (approx. 1.7 million euros).

Starting up a business in Hungary lasts on average 5 days and consists of four procedures: preparation of documents for the company, opening a bank account, registration of companies and registration of social security. Fees on starting up a business are based on approximately 500-1030 euros by the legal 
form of the company (World Bank, 2015a). Insolvency has an average duration of 2 years, the cost is estimated at $14.5 \%$ of company assets. The debtor can pass both liquidation and reorganization. The rate of recovery of the company is $40.2 \%$ (World Bank, 2015a).

\section{Supporting programs at national level}

Hungary belongs to the countries, which have benefitted from a joint initiative of the European
Commission, EIB and EIF JEREMIE for the programming period 2007-2013. The country has a number of management companies that manage funds with the participation of the EIF. This is the Royalton Partners, East Accession BV, Darby Private Equity, 3TS Capital Partners (European Commission, 2015b). The following Table 3 shows results of comparative study and in detail describes the similarities and differences among selected countries.

Table 3. Results of comparative study: the Czech Republic, the Netherlands and Hungary

\begin{tabular}{|c|c|c|c|c|}
\hline & & Netherlands & Czech Republic & Hungary \\
\hline \multirow{8}{*}{ 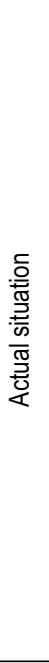 } & Fundraising/HDP 2013 & $0.0124 \%$ & $0.0000 \%$ & $0.0150 \%$ \\
\hline & Average size of fund & $\begin{array}{l}\text { 2007/2013: } \\
86900 \text { / } 12400 \text { thousands EUR }\end{array}$ & $\begin{array}{l}\text { Only } 2010 \text { and } 2011: \\
9025 \text { thousands EUR }\end{array}$ & $\begin{array}{l}\text { 2007/2013: } \\
33000 / 14710 \text { thousands EUR }\end{array}$ \\
\hline & Structures of investors & $\begin{array}{l}\text { 2013: government agencies (30\%), } \\
\text { private persons }(27 \%) \text {, } \\
\text { business investors }(20 \%) \text {, } \\
\text { funds of funds }(11 \%)\end{array}$ & $\begin{array}{l}2010 \text { a } 2011: \\
\text { private persons }(100 \%)\end{array}$ & $\begin{array}{l}\text { 2013: government agencies }(70 \%) \text {, } \\
\text { unclassified }(30 \%)\end{array}$ \\
\hline & In/HDP 2013 & $0.0321 \%$ & $0.0019 \%$ & $0.0176 \%$ \\
\hline & VC/PE 2013 & $55.70 \%$ & $2.10 \%$ & $30.40 \%$ \\
\hline & $\begin{array}{l}\text { Average amount of } \\
\text { investment in } 2013\end{array}$ & $\begin{array}{l}1019 \text { thousands EUR, } 64 \% \\
\text { investments start-up stage (134 } \\
\text { from } 190 \text { enterprises) }\end{array}$ & $\begin{array}{l}463 \text { thousands EUR, } 48 \% \text { of } \\
\text { investments into start-up stage (3from } 6 \\
\text { enterprises) }\end{array}$ & $\begin{array}{l}480 \text { thousands EUR, } 49 \% \text { investments } \\
\text { into start-up stage ( } 21 \text { from } 36 \\
\text { enterprises) }\end{array}$ \\
\hline & Investment areas & $\begin{array}{l}\text { Communication technologies } \\
\text { electrical engineering, health } \\
\text { sciences }\end{array}$ & $\begin{array}{l}\text { Electrical engineering, communication } \\
\text { technologies }\end{array}$ & $\begin{array}{l}\text { Health sciences, energy and } \\
\text { environment, communication } \\
\text { technologies, electronics }\end{array}$ \\
\hline & $\begin{array}{l}\text { Operating Management } \\
\text { companies }\end{array}$ & $\begin{array}{l}45 \text { enterprises, } \\
\text { management in sum of } 1859 \text { mil. } \\
\text { EUR }\end{array}$ & $\begin{array}{l}1 \text { enterprise, } \\
\text { management in sum of } 18 \text { mil. EUR }\end{array}$ & $\begin{array}{l}11 \text { enterprises, } \\
\text { management in sum of } 319 \text { mil. EUR }\end{array}$ \\
\hline \multirow{6}{*}{ 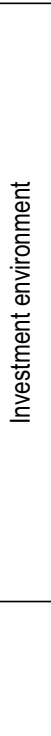 } & $\begin{array}{l}\text { Conditions for pension } \\
\text { funds }\end{array}$ & $\begin{array}{l}\text { Requirement of liquidity and } \\
\text { diversification of investment } \\
\text { portfolio }\end{array}$ & $\begin{array}{l}\text { Transformed funds: max. } 5 \% \\
\text { participating funds: no VC funds }\end{array}$ & Max. $5 \%$ into VC funds \\
\hline & $\begin{array}{l}\text { Conditions for } \\
\text { insurances }\end{array}$ & $\begin{array}{l}\text { Requirement of liquidity and } \\
\text { diversification of investment } \\
\text { portfolio }\end{array}$ & no VC funds & Max. $5 \%$ into VC funds \\
\hline & AIFMD/EuVECA & $\begin{array}{l}\text { AIFMD: implementation 22/7/2013 } \\
\text { EuVECA: } 2 \text { management } \\
\text { companies }\end{array}$ & $\begin{array}{l}\text { AIFMD: implementation 19/8/2013 } \\
\text { EuVECA: no management companies }\end{array}$ & $\begin{array}{l}\text { AIFMD: implementation } 16 / 3 / 2014 \\
\text { EuVECA: no management companies }\end{array}$ \\
\hline & R\&D/HDP & $2,1144 \%$ & $2,0046 \%$ & $1,4447 \%$ \\
\hline & Support of R\&D & $\begin{array}{l}\text { Promotion of cooperation and the } \\
\text { development of networks, grants } \\
\text { and subsidies for research and } \\
\text { development, tax incentives } \\
\text { (employee, business expenses, } \\
\text { capital expenditures, technology } \\
\text { transfer) }\end{array}$ & $\begin{array}{l}\text { Promotion of cooperation and the } \\
\text { development of networks, grants and } \\
\text { subsidies for research and } \\
\text { development,support commercialization } \\
\text { of innovations, tax incentives (corporate } \\
\text { expenses, technology transfer) }\end{array}$ & $\begin{array}{l}\text { Grants and subsidies for research and } \\
\text { development,promotion of cooperation } \\
\text { between countries, tax incentives } \\
\text { (corporate expenses, capital } \\
\text { expenditures, personnel, technology } \\
\text { transfer, cooperation between research } \\
\text { centres, universities and companies) }\end{array}$ \\
\hline & Patents & $\begin{array}{l}\text { Expenditures on registration: } \\
\text { 220/914 EUR, renewal fees ( } 20 \\
\text { years): } 11040 \text { EUR, annual } \\
\text { averages fees: } 552 \text { EUR }\end{array}$ & $\begin{array}{l}\text { Expenditures on registration: } \\
\text { 214/320 EUR, renewal fees ( } 20 \text { years): } \\
\text { 6599 EUR. } \\
\text { annual averages fees: } 330 \text { EUR } \\
\end{array}$ & $\begin{array}{l}\text { Expenditures on registration: } 460 \text { EUR, } \\
\text { renewal fees ( } 20 \text { years): } 7808 \text { EUR, } \\
\text { annual averages fees: } 330 \text { EUR: } \\
390 \text { EUR }\end{array}$ \\
\hline \multirow{4}{*}{ 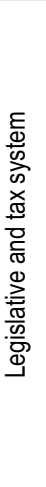 } & Tax transparency & Yes, Limited Partnership (CV) & $\begin{array}{l}\text { Limited Partnershipinvestment sheets } \\
\text { (SICAR), but } 5 \% \text { taxes on income, } \\
\text { since the year } 20150 \%\end{array}$ & $\begin{array}{l}\text { Yes, funds are exempt from tax of } \\
\text { income }\end{array}$ \\
\hline & $\begin{array}{l}\text { Tax exemption } \\
\text { from capital incomes }\end{array}$ & $\begin{array}{l}\text { Yes, if share of investor (PP) in } \\
\text { enterprise is } 5 \text { and more } \% \text {. } \\
\text { Yes, if share of investor (PP) is } \\
\text { less than } 5 \% \text {.Otherwise the rate is } \\
20-25 \% \text {. }\end{array}$ & $\begin{array}{l}\text { No, rate } 15 \% \text {. } \\
\text { Non-residents are exempt only if their } \\
\text { country has concluded an agreement } \\
\text { with the Czech Republic. }\end{array}$ & $\begin{array}{l}\text { No, rate } 16 \% \text {. } \\
\text { Non-residents are exempt only if their } \\
\text { country has concluded an agreement } \\
\text { with Hungary }\end{array}$ \\
\hline & $\begin{array}{l}\text { VAT on services of } \\
\text { management } \\
\text { companies }\end{array}$ & No & No & No \\
\hline & $\begin{array}{l}\text { Difficulty with starting up } \\
\text { a business }\end{array}$ & $\begin{array}{l}\text { 21th place, } \\
\text { duration } 4 \text { days, } \\
\text { fees } 1800 \text { EUR }\end{array}$ & $\begin{array}{l}110^{\text {th }} \text { place, } \\
\text { duration } 19 \text { days, } \\
\text { fees } 1000 \text { EUR }\end{array}$ & $\begin{array}{l}57^{\text {th }} \text { place, } \\
\text { duration } 5 \text { days, } \\
\text { fees } 500-1030 \text { EUR }\end{array}$ \\
\hline
\end{tabular}


Table 3 (cont.). Results of comparative study: the Czech Republic, the Netherlands and Hungary

\begin{tabular}{|c|c|c|c|c|}
\hline & & Netherlands & Czech Republic & Hungary \\
\hline & Dealing the insolvency & $\begin{array}{l}12^{\text {th }} \text { place, duration } 1.1 \text { years, } \\
\text { expenditures: } 3.5 \% \text { of assets, } \\
\text { level of recovery } 88.9 \%\end{array}$ & $\begin{array}{l}20^{\text {th }} \text { place, duration } 2.1 \text { years, } \\
\text { expenditures } 17 \% \text { of assets, } \\
\text { level of recovery } 65.6 \%\end{array}$ & $\begin{array}{l}64^{\text {th }} \text { place, duration } 2 \text { years, } \\
\text { expenditures } 14.5 \% \text { of assets, } \\
\text { level of recovery } 40.2 \%\end{array}$ \\
\hline \multirow{2}{*}{ 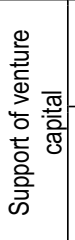 } & $\begin{array}{l}\text { Supporting programs of } \\
\text { venture capital }\end{array}$ & $\begin{array}{l}\text { Seed Capital-regeling, } \\
\text { Groeifaciliteit, } \\
\text { PPM Oost, DVI }\end{array}$ & $\begin{array}{l}\text { None, attempt to set up a seed fund, } \\
\text { not finished. }\end{array}$ & JEREMIE \\
\hline & $\begin{array}{l}\text { Management } \\
\text { companies managing } \\
\text { the funds with EIF } \\
\text { participation }\end{array}$ & 5 enterprises & 8 enterprises & 4 enterprises \\
\hline
\end{tabular}

Source: own.

\section{Discussion}

The problem of undeveloped venture capital market in the Czech Republic is not in demand for venture capital, but in its supply. The Czech Republic reaches almost the same proportion of expenditure on R\&D to GDP as the Netherlands and higher than Hungary. Research and development aid from the state is realized in the various programs. The cost on registering and maintaining patents are lower in comparison with the other two countries. The Czech Republic do not offer favorable tax incentives for the research and development as Hungary, but it may be argued on investments in research and development that they are high. The only problem may be the transformation of research and development to final commercial form, since the Czech Republic is in terms of the difficulty with starting up a business evaluated up to $110^{\text {th }}$ place. In addition to this problem from the perspective of demand, it does not seem a barrier that would avert the development of venture capital investment, and it can be argued that plenty of businesses is the Czech Republic - could be attractive for venture capital investors.

Much problematic seems to be the supply side on the venture capital market in the Czech Republic. If ever VC were funds created in the Czech Republic, their investors have always been a private person. In the Czech Republic, it is not possible for pension companies and insurance companies to invest a part of their resources to $\mathrm{VC}$ funds. It can be argued that neither the Netherlands nor in Hungary pension companies and insurance companies invest in venture capital funds, yet in both countries, $\mathrm{VC}$ funds were created (in 2013). In the Netherlands and Hungary, however, an important role as an investor represents government agencies that through government programs replace the role of institutional investors. In the Netherlands, investors as private persons and companies are strongly represented, whose capital earnings are exempt from income tax. In contrast, in the Czech Republic, there are no tax incentives to attract investors and even government programs that could supplement the missing investors and support the creation of $\mathrm{VC}$ funds.

\section{Conclusion}

The establishment of VC fund in the Czech Republic by the end of 2014 was problematic. With the implementation of AIFMD in Czech legislation through ZISIF, the new legal forms for VC funds were created, which provide a structure to ensure tax transparency. By 2014, all the funds were subject to the tax rate of $5 \%$ and, therefore, there was the risk of double taxation. Since 2015, income tax rate of $0 \%$ pay for all investment funds and for the first time in the Czech Republic the risk of double taxation is averted. A positive fact is also element that the service of management companies of $\mathrm{VC}$ funds are not subject to VAT, but this is common in other countries.

The low level of use of venture capital for the development of enterprises in the Czech Republic can also be seen in misunderstanding and ignorance of this form of financing, the inability of management to prepare a business plan and to attract a potential investor, business fears of administrative burdens arising from an investor and finally questionable return on investment when, e.g., public offering of shares, which achieves a high appreciation, is in the Czech Republic underused.

\section{Acknowledgement}

The research plan has been prepared within the research project "Research of consolidating entities in the Czech Republic" of Internal Grant Agency of the Mendel University with registration number $14 / 2015$.

\section{References}

1. AIFMD in the Netrherlands (Alternative Investment Fund Managers Directive). (2014). In: Eversheds [Online]. Available at: http://www.eversheds.nl/en/newsletter/aifmd_in_the_netherlands_alternative_investment_fund_ managers_directive/. [Accessed 2016, August 13]. 
2. AVCO. (2006). Der Einfluss von Private Equity (PE) und Venture Capital (VC) auf Wachstum und Innovationsleistung österreichischer Unternehmen. Available at: http://www.avco.at/upload/medialibrary/ Impact_von_PE_VC_Endbericht_Okt._2006.pdf. [Accessed 2016, August 13].

3. Busse, F.J. (2003). Grundlagen der betrieblichen Finanzwirtschaft [Bases of Corporate Finance]. $5^{\text {th }}$ ed. Wien: Oldenburg Verlag.

4. BVCA. (2002). The Economic Impact of Private Equity in the UK. Available at: http://www.bvca.co.uk/ assets/features/show/TheEconomicImpactofPrivateEquityintheUK2002.pdf. [Accessed 2016, August 13].

5. De Nederlandsche Bank. (2011). Solvency test for Insurers. Available at: http://www.toezicht.dnb.nl/en/2/51202118.jsp. [Accessed 2016, August 13].

6. Engel, D. (2001). Höheres Beschäftigumgswachstum durch Venture Capital [Higher employment growth through venture capital]. Discussion Paper No. 01-34. Mannheim: ZEW.

7. Engel, D. and Keilbach, M. (2002). Firm level Implications of Early stage Venture Capital Investments - An Empirical Investigation, Discussion Paper No. 02-82.

8. European Commission. (2012). Report of Chairman of the Expert Group on the Cross-border Matching of Innovative Firms with Suitable Investors. Available at: http://ec.europa.eu/transparency/regexpert/index.cfm?do= groupDetail.groupDetailDoc\&id=6008\&no=1. [Accessed 2015, January 05].

9. European Commission. (2015a). Horizon 2020. Available at: http://ec.europa.eu/programmes/ horizon2020/en/what-horizon-2020. [Accessed 2016, August 13].

10. European Commission. (2015b). Access to EU finance. Available at: http://europa.eu/youreurope/business/ funding-grants/access-to-finance/index_en.htm. [Accessed 2016, August 13].

11. EVCA. (2001). Survey of the Economic and Social Impact of Management Buyouts and Buyin in Europe. Research paper, I. Brussels: EVCA.

12. EVCA. (2013). AIFMD Essentials: A Guide to the Alternative Investment Fund Managers Directive. Available at: http://www.evca.eu/media/299189/aifmd-essentials-december-2013-preview.pdf. [Accessed 2016, August 13].

13. EVCA. (2014). European Private Equity Activity Data 2007 - 2013. Available at: http://www.evca.eu/media/ 165475/yearbook-2014-europe-country-tables-final.xlsx. [Accessed 2015, March 16].

14. Geyer, A. Hanke, M. and Littich, E. (2006). Grundlagen der Finanzierung [Bases of Financing]. $2^{\text {nd }}$ ed. Wien: Linde Verlag Wien.

15. Hebák, P. et al. (2007). Vicerozmérné statistické metody [Multivariate statistical methods]. $2^{\text {nd }}$ ed. Praha: Informatorium.

16. Hungarian Intellectual Property Office. (1996-2014). Patent. Available at: http://www.sztnh.gov.hu/English/ szabadalom/. [Accessed 2015, March 31].

17. Jain, B. A. and Kini, O. (1995). Venture Capitalist Participation and the Post-issue Operating Performance of IPO firms, Managerial and Decision Economics, 16, pp. 593-606.

18. Koëter, M. (2012). Boosting the venture capital sector in the Netherlands after the financial crisis. Master Thesis. Tilburg: Tilburg University, Tilburg Law School. Available at: http://arno.uvt.nl/show.cgi?fid=128736. [Accessed 2016, August 13].

19. Lerner, J. (1999). The Government as Venture Capitalist, Journal of Business Venturing, 72, No. 3, pp. 285-318.

20. Manigart, S. and Van Hyfte, W. (1999). Post Investment Evolution of Venture Backed Companies. In Frontiers of Entrepreneurship Research. Wellesley, MA: Babson College. Mannheim: ZEW.

21. Netherlands Enterprise Agency. (2015). Fees. Available at: http://english.rvo.nl/topics/innovation/patents-other-iprights/patents/fees. [Accessed 2015, March 28].

22. NVCA. (2001). Measuring the Importance of Venture Capital and Its Benefits to the United States Economy. Research paper, I. New York: NVCA.

23. Nývltová, R. and Režňáková, M. (2007). Mezinárodní kapitálové trhy: zdroj financování [International capital markets: source of financing]. $1^{\text {st }}$ ed. Praha: Grada Publishing.

24. OECD. (2004). Venture Capital: Trends and Policy Recommendations. Available at: http://www.oecd.org/ industry/ind/28881195.pdf. [Accessed 2015, March 2].

25. OECD. (2014). Annual Survey of Investment Regulation of Pension Funds (2014). Available at: $\mathrm{http} / /$ www.oecd.org/daf/fin/private-pensions/2014\%20Survey\%20of\%20Investment\%20Regulations\%20of\%20 Pension\%20Funds\%20FINAL.pdf. [Accessed 2016, August 13].

26. Pazour M. and Marek, D. (2011). Fondy rizikového kapitálu s účastí soukromých a veřejných finančních prostředkü [Venture capital funds with the participation of private and public funds]. [Online]. Available at: http://www.vyzkum.cz/storage/att/18C0C6E0BEDC982432D14A62BD739099/A\%204-8\%20VC\%20fondy.pdf. [Accessed 2016, August 13].

27. Peneder, M. and Jud, T. (2004). Empirische Untersuchungen und zur Wirkung von Private Equity und Venture Capital auf die Unternehmensentwicklung. [Empirical studies and findings on the effect of private equity and venture capital to the enterprise development]. Available at: http://www.avco.at/AVCO.aspx?target=21865. [Accessed 2016, August 13].

28. Rajchlová, J., Fedorová, A. and Svatošová, V. (2014). The Venture Capital in the Czech Companies: Development of Number of Employees and Efficiency of Employees, Investment Management and Financial Innovations, 11 (1), pp. 77-86. 
29. Rajchlová, J., Zinecker, M. and Brož, Z. (2012). Due Diligence Process in the Context of Pri-vate Equity and Venture Capital Financing in the Czech Republic, Economics, 1, pp. 15-23.

30. Roling, J. (2001). Venture Capital und Innovation. $1^{\text {st }}$ ed. J. Eul Verlag.

31. Schefcyk, M. (2006). Finanzieren mit venture capital und private equity [Financing with venture capital and private equity]. Berlin: Schaffer, Poeschel.

32. The World Bank. (2015a). Ease of doing business in Czech Republic. Available at: http://www. doingbusiness.org/data/exploreeconomies/czech-republic/\#starting-a-business. [Accessed 2016, August 13].

33. The World Bank. (2015b). Ease of doing business in Hungary. Available at: http://www.doingbusiness.org/data/ exploreeconomies/hungary/\#starting-a-business. [Accessed 2016, August 13].

34. The World Bank. (2015c). Rankings. Available at: http://www.doingbusiness.org/rankings. [Accessed 2016, August 13].

35. ÚPV: Úřad průmyslového vlastnictví. [Office of Industrial Property]. (2011). Poplatky [Fees]. Available at: http://www.upv.cz/cs/prumyslova-prava/vynalezy-patenty/poplatky.html. [Accessed 2016, August 13].

36. Valach, J. (2001). Investiční rozhodování a dlouhodobé financování [Investment decision-making and long-term financing]. $1^{\text {st }}$ ed. Praha: Ekopress. 